\title{
The Effects of Particle Shape on Bond Strength Improvement of Epoxy- Particle Coating Composites
}

\author{
Jiang-Jhy Chang \\ Department of Harbor and River Engineering, National Taiwan Ocean University, Keelung, 202 Taiwan, ROC. \\ Wei-Chung Yeih \\ Department of Harbor and River Engineering, National Taiwan Ocean University, Keelung, 202 Taiwan, ROC.
}

Follow this and additional works at: https://jmstt.ntou.edu.tw/journal

Part of the Civil and Environmental Engineering Commons

\section{Recommended Citation}

Chang, Jiang-Jhy and Yeih, Wei-Chung (2001) "The Effects of Particle Shape on Bond Strength Improvement of EpoxyParticle Coating Composites," Journal of Marine Science and Technology: Vol. 9: Iss. 2, Article 11.

DOI: 10.51400/2709-6998.2446

Available at: https://jmstt.ntou.edu.tw/journal/vol9/iss2/11

This Research Article is brought to you for free and open access by Journal of Marine Science and Technology. It has been accepted for inclusion in Journal of Marine Science and Technology by an authorized editor of Journal of Marine Science and Technology. 


\title{
THE EFFECTS OF PARTICLE SHAPE ON BOND STRENGTH IMPROVEMENT OF EPOXY- PARTICLE COATING COMPOSITES
}

\author{
Jiang-Jhy Chang and Wei-Chung Yeih
}

Keywords: bond strength; epoxy coating; corrosion prevention.

\begin{abstract}
In this paper the effect of particle shape on the bond improvement of epoxy-particle coating composite is evaluated. In our previous studies, it has been shown that adding foreign particles in the epoxy may enhance the bond characteristics of coating. It has been found that the enhancement of bond for coating by adding foreign particles in epoxy may come from two reasons: one comes from the mechanical improvement by foreign particles and the other comes from the chemical reaction of foreign particles which yields a better binding material. In our previous study, the size of foreign particle influenced the degree of mechanical improvement has been concluded. However, how does the shape of foreign particles influence the bond improvement of coating remains a challenging topic. We used three kinds of foreign particles with similar mechanical behavior and similar size. They are a ASTM C778 standard sand (size of $778 \mu \mathrm{m}$ ), a river sand (size of $600 \mu \mathrm{m}$ ) and a silica sand (size of $600 \mu \mathrm{m}$ ). The shape of ASTM C778 standard sand close to a sphere, the shape for the river sand is most irregular and the shape of silica sand is between the former two. Experimental results show that under the same weight ratio of foreign particle/epoxy river sand shows a best improvement of bond strength and C788 standard sand shows a worst improvement among them. Other bond characteristics, the shear stiffness per unit embedded length and the critical debonding shear load per unit embedded length, have the similar trend as the bond strength. From these results, it is concluded that the wedge effect of irregular shape particle contributes a lot to the bond improvement. Electrochemical experiments were conducted to show the corrosion prevention capacity of coatings, results revealed that adding foreign particles inside the epoxy did not influence the corrosion capacity of coating.
\end{abstract}

\section{INTRODUCTION}

Increasing use of coated rebar to prevent possible damage from corrosion in Northern America has been reported [1]. It has been widely accepted that epoxy coated rebar can prevent corrosion due to the prevention capacity of penetration of hazard agents through a dense coating. Although possible damage of coating may

Paper Received August 30, 2000. Revised November 21, 2001. Accepted December 6, 2001. Author for Correspondence: J. J. Chang.

*Department of Harbor and River Engineering, National Taiwan Ocean University, Keelung, 202 Taiwan, ROC. result in a more serious corrosion of rebar [2], coated rebar is still popular nowadays. Careful work with coated rebar has been suggested to prevent scratch of coating, which is thought to be possible technically. However, there exists another drawback using coated rebar that is thought to be unavoidable; that is the bond strength loss. It is well known that coated rebar loses its bond strength reported in many research articles [3-5]. Due to this, ACI [6] and ASSHTO [7] suggest a modification on the design parameters, e.g., the splice length. However, increment of these parameters mean more rebar should be used and thus becomes not economical.

Instead of modifying design parameters, Tsai [8] has proposed a different idea: adding some foreign particles in epoxy coating to enhance its bond characteristics. Following this, Chang et al. [9] has reported a size effect of sand used on the improvement of bond. In their researches, foreign particles were added in the epoxy to form a better coating composite by the mechanical enhancement. Later, Yeih et al. [10] has used fly ash as the foreign particle. They found that the pozzolan reaction effect of fly ash enhanced the bond characteristics chemically. From the experience of composite engineering, we know that to improve the material property we need to add some better-performed particles inside the matrix. Such particles can improve total behavior of the composite either by their better property or by its chemical reaction to form a better one. To add sand in epoxy belongs to the first kind. Theoretically speaking, the mechanical behaviors of sand, the volume ratio of sand, the size of sand and the shape of sand may influence the final property of this sand-epoxy composite. In this study, the effect of shape of sand is evaluated. Three different shapes of sand, the ASTM C778 standard sand, silica sand and river sand, with similar mechanical property and size were used. Among them, the shape of ASTM C778 sand mostly close to a sphere and shape of river sand is mostly irregular. A single rebar pullout test [11-13] was conducted to evaluate several bond characteristics: the bond strength, the shear stiffness per unit embedded length and the critical debonding shear load per unit embedded length. 
Furthermore, an open circuit potential experiment and a DC linear polarization method for instantaneous corrosion rate measurement were both conducted to evaluate the corrosion prevention capacity of coating.

\section{EXPERIMENTAL}

\section{Materials}

A unified concrete mix of w/c ratio equal to 0.62 was used. The details for the concrete mix design are listed in Table 1. The average 28 -days compressive strength of the concrete was $23 \mathrm{MPa}$. Number 4 rebar was used with a Young's modulus of $203 \mathrm{GPa}$ and yield strength of 409MPa. The geometrical properties of the rebar are shown in Table 2. The epoxy used was Ameron Amerlock $400^{\circledR}$. Three foreign particles were adopted: ASTM C778 standard sand, silica sand and river sand. The size of ASTM C778 standard sand, silica sand and river sand was $778 \mu \mathrm{m}, 600 \mu \mathrm{m}$ and 600 $\mu \mathrm{m}$, respectively. Since the main chemical composition of these three foreign particles is $\mathrm{SiO}_{2}$, their mechanical properties were very close (i.e., their strength and their Young's modulus were close). The chemical composition of silica sand is tabulated in Table 3.

\section{Variables design and parameters measured}

In this study, the main issue was the bond strength improvement by different shape of foreign particles. To simplify our research, it was better to use the concrete and epoxy material with properties unchanged. Therefore, as stated in the previous subsection, only one concrete mix design was chosen. To keep the epoxy coating material unchanged, the single epoxy was used and the coating thickness was controlled such that bond strength comparisons would be simple. For this reason, we choose a coating thickness of $250 \pm 30 \mu \mathrm{m}$. By keeping other factors unchanged, three kind of foreign particles, ASTM C778 standard sand, silica sand and river sand, were used. The size of ASTM C778 standard sand, silica sand and river sand was 778, 600 and 600 $\mu \mathrm{m}$, respectively. The reason why we did not use all particles of same size is that $778 \mu \mathrm{m}$ is not a standard sieve size such that a sieve size of $600 \mu \mathrm{m}$ (sieve \#30) was thus used. Among these three foreign particles, the shape of ASTM C778 sand was mostly close to a sphere and the shape of river sand was mostly irregular. Since $\mathrm{SiO}_{2}$ was the main chemical composition for these three foreign particles, they show similar mechanical properties. Our purpose is to see the shape effect on the bond strength enhancement. For ASTM C778 standard sand, the weight ratios of foreign particle/epoxy were $200 \%, 400 \%$ and $600 \%$. For other foreign particles, the
Table 1. Mix design for concrete $(w / c=0.62)$

\begin{tabular}{lc}
\hline Materials & Mix proportions $\left(\mathrm{kg} / \mathrm{m}^{3}\right)$ \\
\hline water & 193 \\
ASTM type I cement & 311 \\
sand & 889 \\
coarse aggregate & 971 \\
\hline
\end{tabular}

Table 2. configuration of \#4 rebar

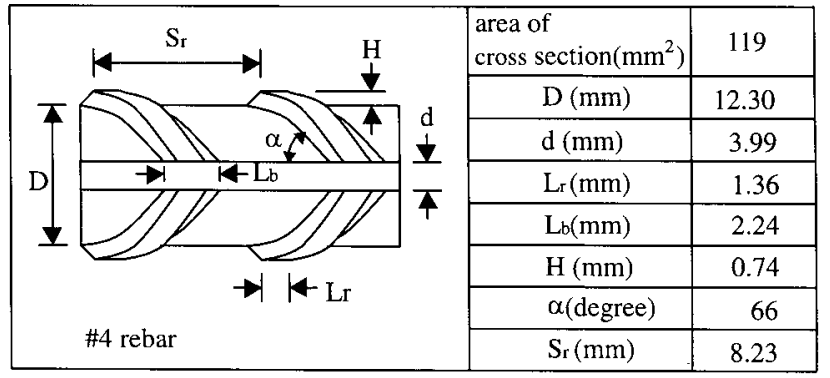

Table 3. Chemical compositions of silica sand

\begin{tabular}{cc}
\hline Chemical composition & Weight percentage \\
\hline $\mathrm{SiO}_{2}$ & 97.82 \\
$\mathrm{Al}_{2} \mathrm{O}_{3}$ & 1.51 \\
$\mathrm{Fe}_{2} \mathrm{O}_{3}$ & 0.06 \\
$\mathrm{MgO}$ & 0.18 \\
$\mathrm{CaO}$ & 0.28 \\
\hline
\end{tabular}

weight ratios of foreign particle/epoxy were $100 \%$, $200 \%$ and $400 \%$. From this designation, weight ratios of $200 \%$ and $400 \%$ are those we make comparisons.

During the specimen pullout tests, the pullout load values and slip displacement values of the rebar were recorded. As shown in Fig. 1, the average displacement value from two LVDTs actually represents the slip displacements at the very point one clips the rebar. This location may vary from one experiment to another. To have the displacement at the same position, one can use a modified formula such as [14]

$$
U_{\text {cal }}=U_{\text {measured }}-\frac{P L_{\text {off }}}{E_{f} A_{f}}
$$

where $U_{c a l}$ is the calculated displacement of point A on the rebar, which just near the concrete surface as shown in Fig. 1. U $U_{\text {measured }}$ is the measured displacement at the point of clipping point B shown in Fig. 1. $P$ is the pullout load. $L_{\text {off }}$ is the offset length, the distance between points A and B. $E_{f}$ is the Young's modulus of the rebar and $A_{f}$ is the nominal cross-sectional area of the rebar. 
A typical pullout force versus displacement curve is sketched in Fig. 2. In this figure, $P^{*}$ is the same as $P$ and $U^{*}$ is the same as $U_{c a l}$, i.e., the displacement at point A. There exist three stages in the pullout test. In the first stage, the load and displacement keeps a linear proportional relationship and no debonding occurs in this stage. The slope of $\mathrm{P} / \mathrm{U}$ is then called the shear stiffness, $K_{s}$. However, the shear stiffness increases as

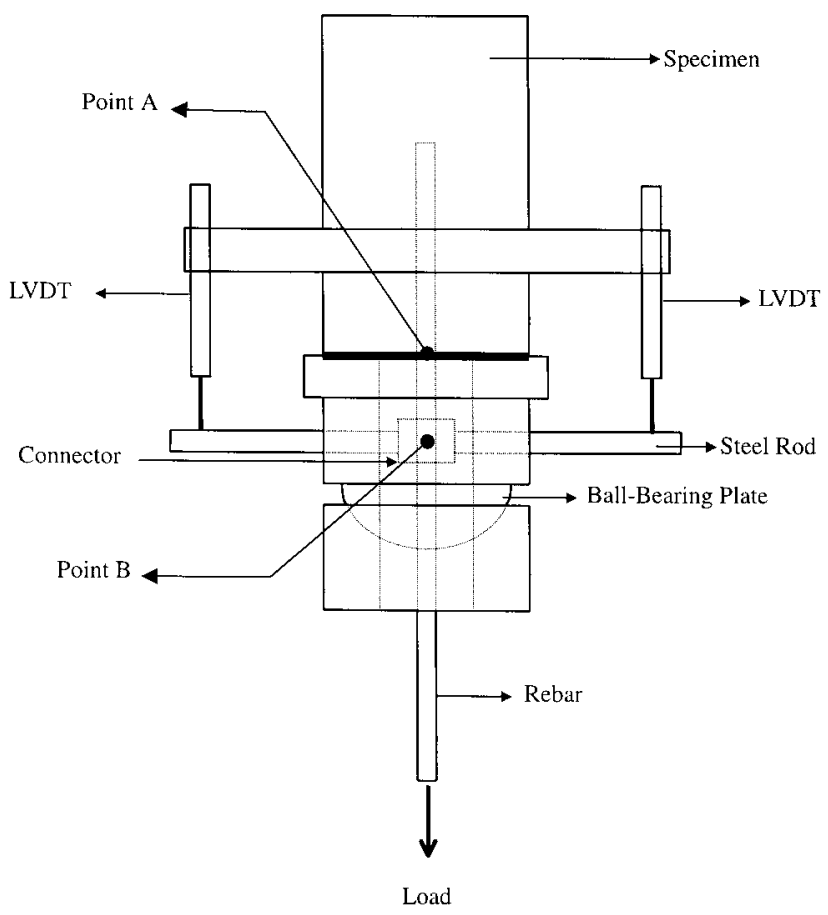

Fig. 1. Displacement calculation for rebar near the concrete surface.

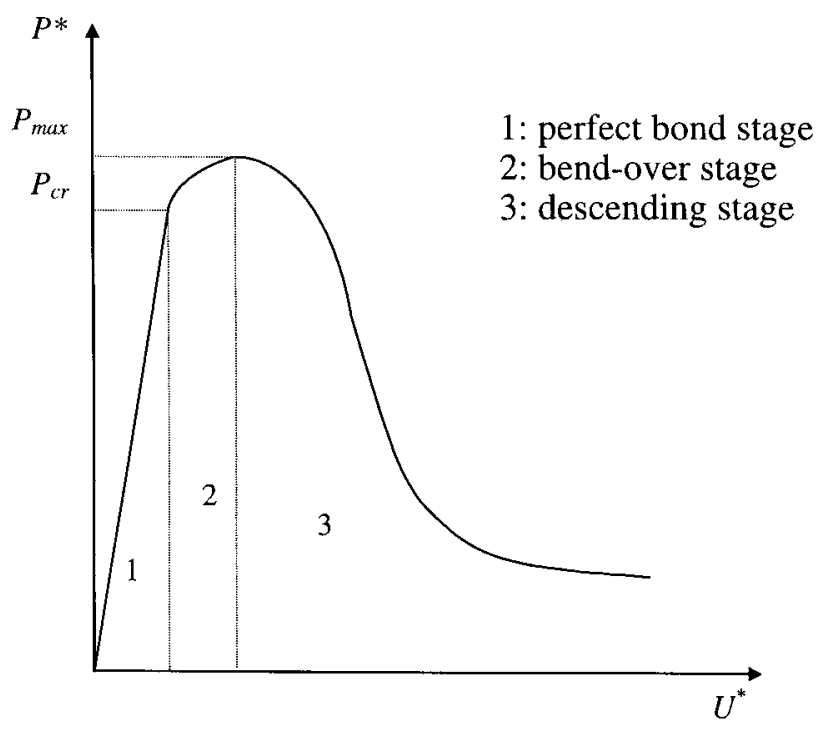

Fig. 2. A typical pullout load diagram versus displacement curve. the embedded rebar length increases, and thus is not a constant. In [13], a parameter called the shear stiffness per length is defined as

$$
K=\frac{K_{s}}{L_{e m b}}
$$

where $K$ is the shear stiffness per unit embedded rebar length and $L_{e m b}$ is the embedded length of the rebar. It is shown in [13] that this parameter is constant while the rebar geometry is unchanged. After a critical load, $P_{c r}$, the curve bends such that the stiffness decreases. This critical load also depends on the embedded length. For the same reason we follow the definition in [13] to define the critical shear debonding load per unit embedded length $q_{y}$ as

$$
q_{y}=\frac{P_{c r}}{L_{e m b}}
$$

The second stage is called the bend-over stage due to its curve shape. The load then reaches the maximum, $P_{\max }$. From the maximum pullout load, one can define the bond strength by dividing it by the nominal embedded area of the rebar. After the maximum pullout load, the curve descends as shown in Fig. 2. This stage is called the descending stage.

The above-mentioned three parameters were used in this study to evaluate the bond characteristics.

\section{Preparation of pullout specimens and experiments conducted}

The rebar was cleaned using \#200 sandpaper to remove surface rust before coating. Different composite coating materials were prepared by mixing different foreign particles with designated amounts into the epoxy as stated previously in subsection 2. The coating was applied to the surface of each rebar using a paint brush. The coated rebar was then cured at $200^{\circ} \mathrm{C}$ for one hour after coating to achieve the best coating properties according to manufacturer's suggestions. To ensure the thickness coating control, for each specific group of designated variables we painted 20 rebar, then the coating thickness of each rebar was measured at 30 points. Eight rebar with the required thickness range for our requirement were selected as pullout specimens. Our previous experience indicated that if the embedded length was too long then unwanted splitting failure might occur. To guarantee a sliding failure along the interface, the embedded length was only $40 \mathrm{~mm}$, determining using a preliminary test. The exact embedded length of each specimen was measured individually. The specimens were cast in steel molds and demolded 24 hours later and cured in lime-saturated water for 28 days. To ensure the position of the rebar, we used a 
device to stabilize the rebar location, as shown in Fig. 3. After the curing process, the specimens were then loaded into a testing machine, as shown in Fig. 4. The machine pulls the rebar at a rate of $1.27 \mathrm{~mm} / \mathrm{min}$. Pullout test was conducted basically according to the specification in ASTM C 234-91. The pullout displacement and force were measured using LVDTs and a load cell, and recorded using a data acquisition system. In order to calculate the desired displacement, as mentioned in subsection 2, the offset length $L_{\text {off }}$ was recorded for each specimen. For each group, once an unwanted splitting failure occurred in a specimen, it was discarded from that group. Among all 8 specimens, at least 6 specimens had the desired pullout failure in our experiments. Using four specimens from successful trials in one group, we obtain the average bond characteristics for this specific group.

To evaluate the corrosion prevention ability of rebar, the same rebar from each group (with or without coating) was immersed in a $3.5 \% \mathrm{NaCl}$ solution and tested using the open circuit potential and direct current polarization methods. The instantaneous corrosion rates then were calculated using the Stern-Geary equation [15].

\section{RESULTS AND DISCUSSION}

\section{The bond strength}

The average bond strength for uncoated rebar was reported as $7.43 \mathrm{Mpa}$. The average bond strength for pure epoxy coated rebar was about $6.52 \mathrm{MPa}$. It can be

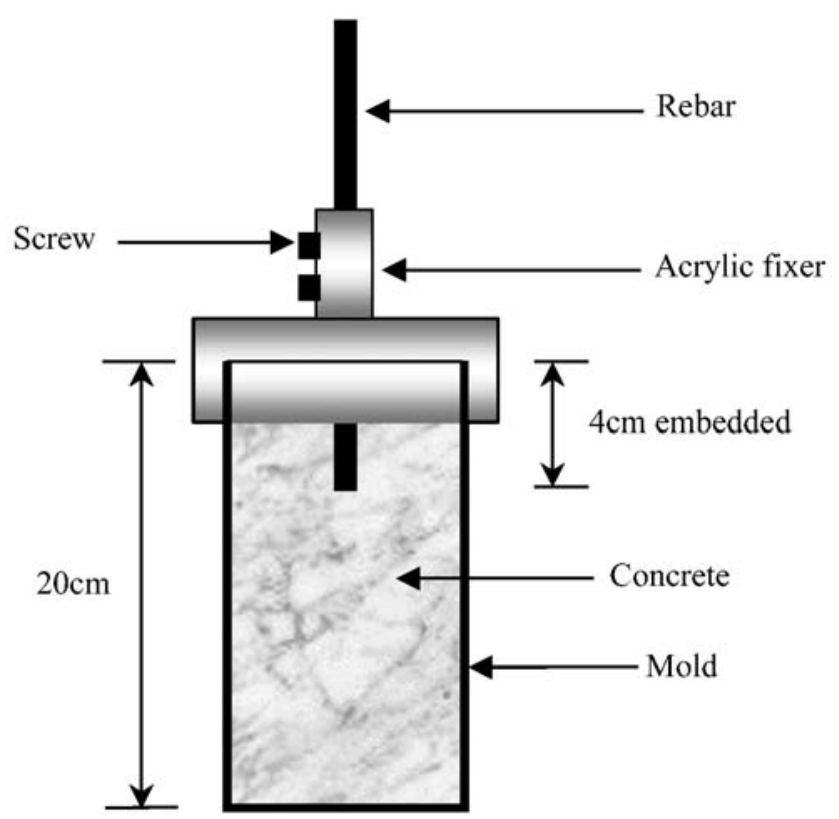

Fig. 3. Preparation for the pullout specimen. seen that there exists a $12 \%$ decrease in bond strength when epoxy-coated rebar was used. The bond strengths for various foreign particle-epoxy coating materials are illustrated in Fig. 5. In this figure, the dotted line means the average bond strength for naked rebar and the solid line means the average bond strength for pure epoxy

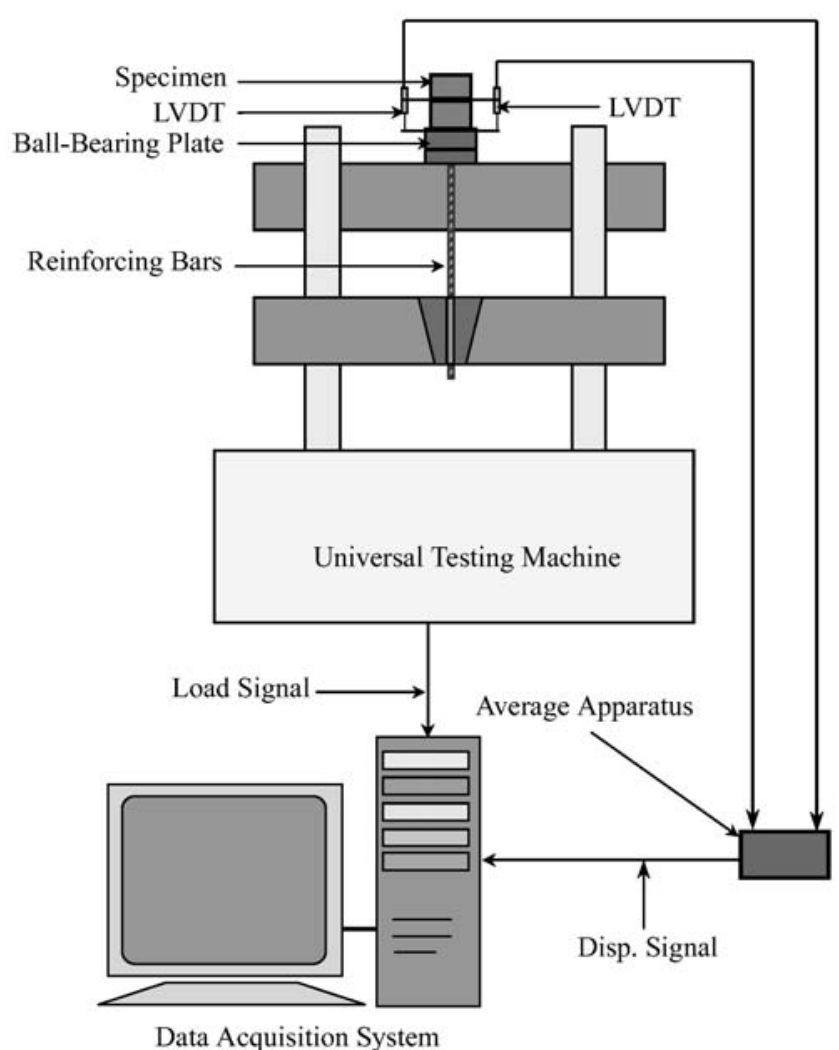

Fig. 4. The single-rebar pullout test setup.

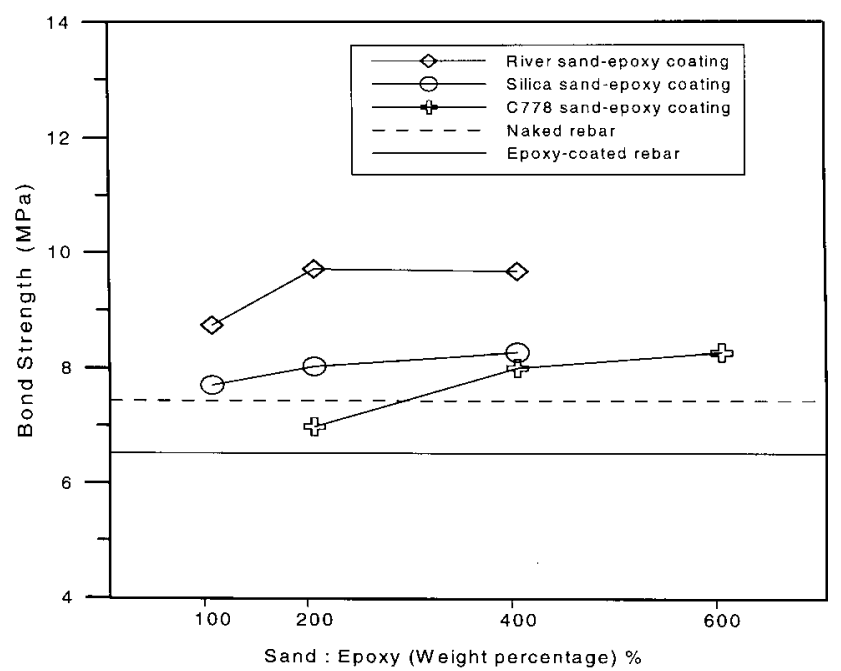

Fig. 5. Bond strength comparison for various coatings. 
coated rebar. It can be found that under the same weight ratios $(200 \%$ and $400 \%)$ the enhancement of bond strength is most apparent for the river sand, the second one is the silica sand and the worst one is ASTM C778 sand. Furthermore, for the ASTM C778 group and silica sand group a better enhancement in bond strength was found as increment in weight ratio. Nevertheless, the bond improvement for the river sand group reached an optimal value at a weight ratio of $200 \%$ then decreased as increasing usage of river sand.

This trend can be explained as follows. To improve the coating property, one can add a better-behaved particle inside the coating to form a composite. Assuming no chemical reaction between foreign particles and epoxy, the influences of a foreign particle are its volume ratio, its mechanical properties, its size and its shape. In a previous research [9], the effects of size and volume ratio were reported. From the point of composite materials, once such a particle is added the property should improve more as the volume fraction of this particle increases, provided that this composite is a sound composite. From this point of view, one can claim that if the amount of foreign particles increases the mechanical behavior of such a composite should be better. Nevertheless, one condition is very important, that is the composite should be sound. This means that the biding force between the epoxy and the foreign particles should be perfect. However, as the amount of foreign particles increases, the amount of epoxy may not be enough to cover each particle such that the composite becomes unsound and the mechanical strength decreases as a result. According to this, when the amount of particles exceeds a critical value the bond strength starts to decrease as the amount of particles increases. In our result, for ASTM C778 standard sand and silica sand the amount used in our designations did not exceed their critical values such that no decreasing could be found as we increased their weight ratios. On the other hand, the river sand group showed a critical usage at a weight ratio of $200 \%$. We explained this phenomenon by the shape of foreign particles. Remember that the condition we can have a sound composite is that enough epoxy is used such that each foreign particles can be covered. It means that the surface area of a foreign particle decides at least how much epoxy should be used. The river sand, that has a more irregular shape than others, then is expected to need more epoxy to have a good coverage.

When the shape of a particle is more irregular, the shear resistance then will become stronger as shown in our result. The reasons come from two parts. The first part comes from a larger friction force. It is well known that a more irregular particle will result in a more apparent friction as it relatively moves with respect to a contact body as shown in Fig. 6(a). Another part comes from a better wedge effect. When particles are more irregular, contacts of them form a better interlock force due to more wedge effects as shown in Fig. 6(b). From this explanation, it is then easy to understand that why river sand group had a best improvement in bond strength and ASTM C778 standard sand had a worst improvement.

\section{The shear stiffness per unit length and critical debonding shear force per unit length}

The shear stiffness per unit length, $\mathrm{K}$, also had the same trend as the bond strength, as illustrated in Fig. 7. The critical debonding shear force per unit length, $q_{y}$, showed a similar trend as shown in Fig. 8. The critical debonding shear force per unit length, $q_{y}$, represents the binding soundness for the concrete to rebar. When a pure epoxy coating is applied, the value of $q_{y}$ drops which means that the binding characteristics decrease. However, when sand (no matter which kind) is added appropriately to the coating, additional interlock force and frictional force were contributed. The shear stiffness per unit length, $K$, represents the rigidity of this composite to a load. It then can be said that appropriately adding sand (no matter which kind) can improve the stiffness of the coating. The reasons for improve-

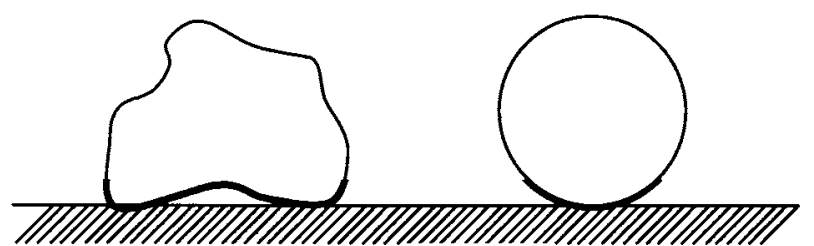

(a)

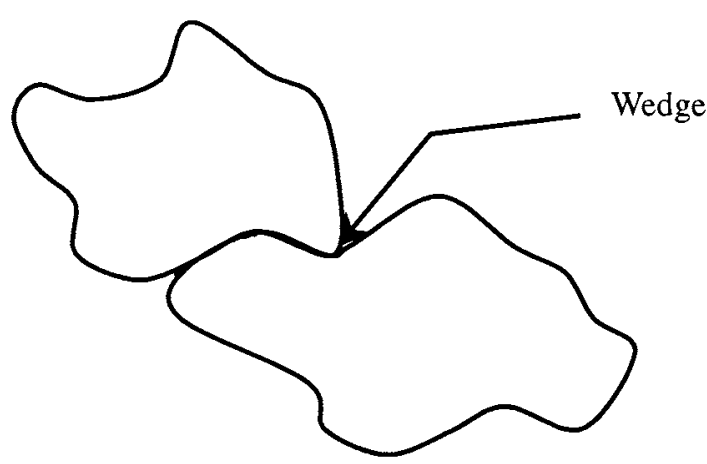

(b)

Fig. 6. Effects of an irregular shape: (a) more contact frictional forces, (b) more interlock forces due to wedges. 
ment have been mentioned earlier in subsection 1 .

\section{The electrochemical experiments}

Electrochemical experiments were performed to examine the corrosion prevention capacity of various coating composites. As shown in Fig. 9, the coated rebar all had a nobler open circuit potential than naked rebar. Not much difference in potentials could be found for these coated rebar. This means that they all have the same corrosion trend. Furthermore, the instantaneous corrosion rates were recorded as shown in Fig. 10. It can be seen in this figure that once rebar is coated, the corrosion rate becomes negligible compared to naked rebar. This once again confirmed our idea that adding

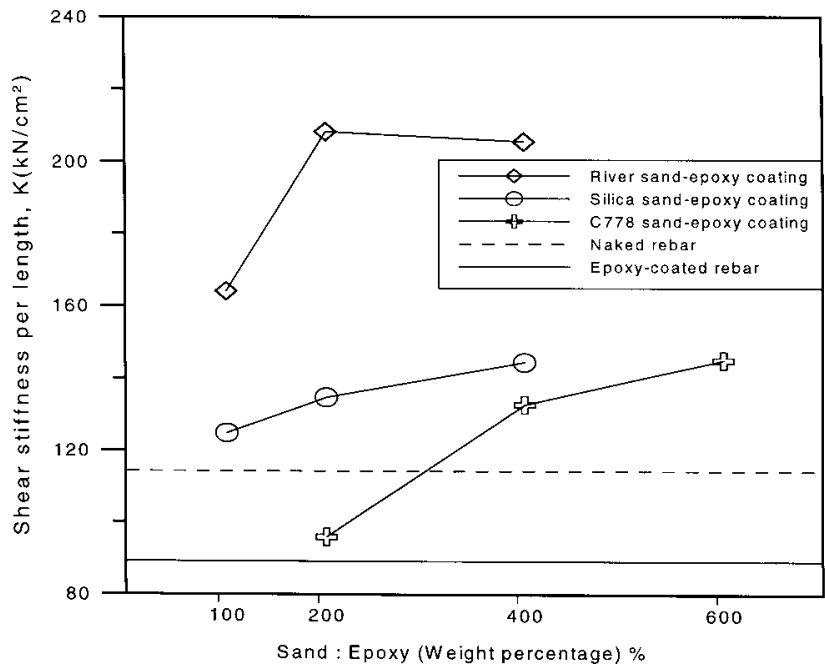

Fig. 7. The shear stiffness per unit length, $K$, for various coatings.

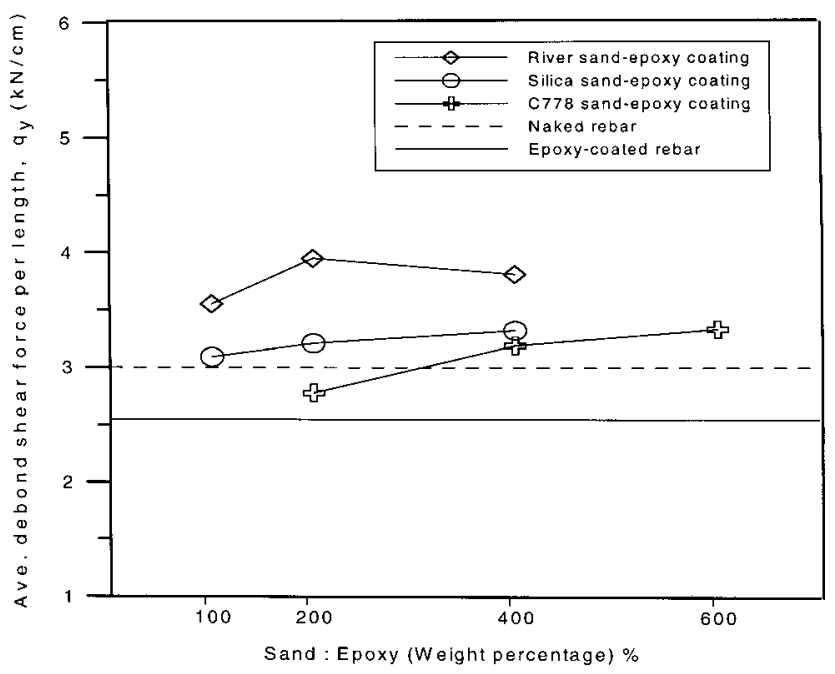

Fig. 8. The critical debonding shear force per unit length, $q_{y}$, for various coatings. foreign particles into the epoxy coating can improve the bond characteristics and still maintain the corrosion prevention capacity. It should be mentioned here that in these two figures only groups of foreign particles with common weight ratios are demonstrated (that is only data with weight ratios of $200 \%$ and $400 \%$ are used). However, experiments for other groups have been also conducted and not much difference can be found.

\section{CONCLUSION REMARKS}

In this study, the shape effect of foreign particle on the bond characteristics of sand-epoxy coating is evaluated by use of three different sands with a similar size and mechanical properties: ASTM C778 standard sand,

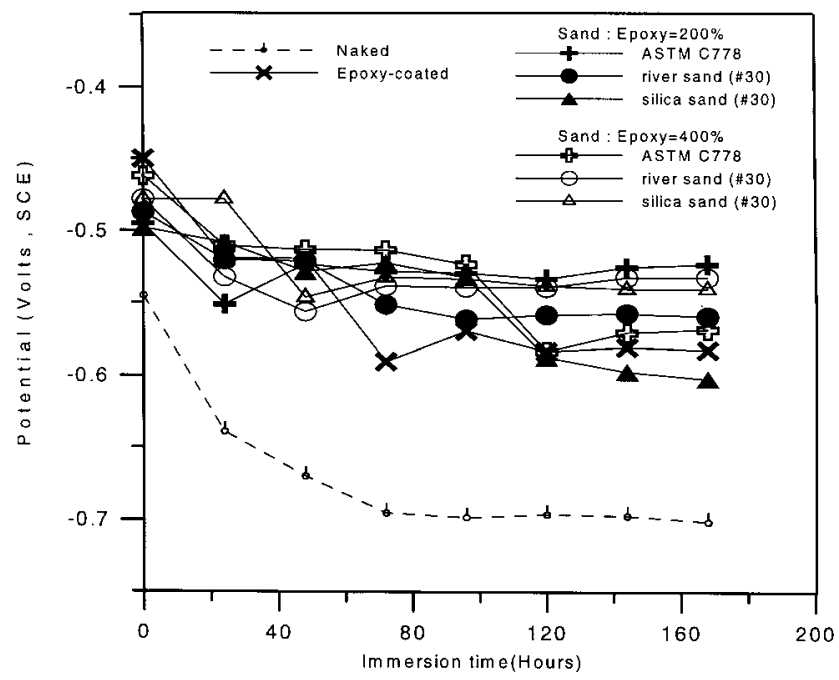

Fig. 9. Open circuit potentials for various coatings.

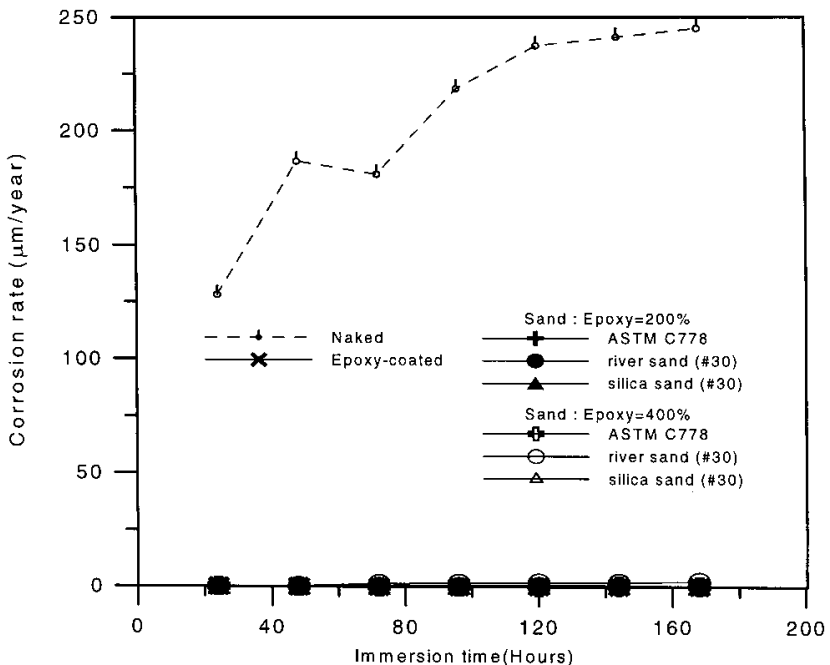

Fig. 10. Instantaneous corrosion rates for various coatings. 
silica sand (sieve size of \#30) and river sand (sieve size of \#30). It was found that the bond strength, the shear stiffness per length and the critical debonding shear load per length all had the same trend. For the river sand group, a weight ratio of $200 \%$ is the optimal usage proportion to achieve a best bond. For other kinds of sand, increasing amount of foreign particles increased bond characteristics within our designated range. Under the same weight of ratio, river sand shows a best improvement in bond characteristics while silica sand is the second and ASTM C778 sand is the worst one. From these experimental results, it is concluded that the irregular shape of foreign particles needs more epoxy usage to ensure a sound coating composite. Furthermore, a more irregular shape of foreign particles can contributes more in frictional forces and interlock forces thus increases bond characteristics more apparently. Electrochemical experiments demonstrated that adding sand to the epoxy composite maintains the corrosion prevention capacity.

\section{REFERENCES}

1. Manning, D. G., "Corrosion Performance of Epoxycoated Reinforcing Steel: North American Experience", Construction and Building Materials, Vol. 10, No. 5, pp. 349-365 (1996).

2. Clearly, D. B. and Ramirez, J. A., "Bond Characteristics of Epoxy-coated Reinforcing Bars", ACI Materials Journal, Vol. 88, No. 2, pp. 146-149 (1991).

3. Bilal, S. H., "Comparative Bond Strength of Coated and Uncoated Bars with Different Rib Geometries", $A C I$ Materials Journal, Vol. 92, No. 6, pp. 579-590 (1995).

4. Kayyali, O. A. and Yeomans, S. R., "Bond and Slip of Coated Reinforcement in Concrete", Construction and Building Materials, Vol. 9, No. 4, pp. 219-226 (1995).

5. Choi, O. C., Hadje-Ghaffari, H., Darwin, D. and McCabe,
S. L., "Bond of Epoxy-coated Reinforcement: Bar Parameters", ACI Materials Journal, Vol. 88, No. 2, pp. 207-217 (1991).

6. ACI Committee 318, Building code requirements for reinforced concrete (ACI 318-95) and commentary (ACI 318R-95), American Concrete Institute, Detroit (1995).

7. Standard Specification for Highway Bridges, The fourteenth edition, American Association of State Highway and Transportation Officials, Washington, DC (1989).

8. Tsai, C. L., "Study of Enhancing Bond Strength of Concrete to Coated Rebar", Proceeding of the Third Structure Engineering Conference, Kenting, Taiwan, pp. 651-659 (1996).

9. Chang, J. J., Yeih, W. and Tsai, C. L., "Enhancement of Bond Strength for Epoxy-coated Rebar Using River Sand", Accepted by Construction and Building Materials (2001).

10. Yeih, W., Chang, J. J. and Tsai, C. L., "Epoxy Coating Bond Strength Enhancement by Adding Fly Ash", Submitted to Cement, Concrete and Composite (2001).

11. El-Hawary, M. M., "Evaluation of Bond Strength of Epoxy-coated Bars in Concrete Exposed to Marine Environment", Construction and Building Materials, Vol. 13, pp. 357-362 (1999).

12. Abrishami, H. H. and Mitchel,l D., "Simulation of Uniform Bond Stress", ACI Materials Journal, Vol. 89, No. 2, pp. 161-168 (1992).

13. Yeih, W., Huang, R., Chang, J. J. and Yang, C. C., "A Pullout Test for Determining Interface Properties between Rebar and Concrete", Advanced Cement Based Material, Vol. 5, pp. 57-65 (1997).

14. Gere, J. M., Mechanics of Materials, Brooks/Cole, USA (2001).

15. Stern, M. and Geary, A. L., "Electrochemical Polarization, I. A Theoretical Analysis of the Shape of Polarization Curves", Journal of Electrochemical Society, Vol. 104, pp. 56-63 (1957). 


\title{
顆粒形狀對含砂環氧樹酯漆封鋼筋 握裹強度改善之研究
}

\author{
張 建 智葉 爲 忠
}

國立台灣海洋大學河海工程學系

\section{摘 要}

本文係針對環氧樹酯與外加顆粒的塗層複合材 料中外加顆粒的形狀對塗封鋼筋的握裹改善作一研 究。以往的研究指出, 在環氧樹酯塗層加入顆粒可以 增進塗層的握裹特性。並且在環氧樹酯塗層加入顆粒 可以增進握裹特性有兩種機制：其中一種是因爲外加 的顆粒本身有較好的機械性質所以造成整體複合材料 的行爲較好, 另外一種是因爲外加顆粒與環境中的成 份產生化學反應而產生機械性質更優良的膠結材料。 在過去的研究當中, 我們已經針對外加顆粒尺寸的影 響討論; 然而, 顆粒的形狀是如何影響握裹特性的改 善並未加以探討。在本研究當中, 使用三種砂料作爲 外加顆粒, 這些砂料有類似的力學行爲並有相近的尺 寸。這些砂料分別是ASTM C778標準砂 ( 尺寸爲778 $\mu \mathrm{m}$ ）、河砂（尺寸爲600 $\mu \mathrm{m}$ ）以及矽砂（尺寸爲 $600 \mu \mathrm{m})$ 。試驗結果顯示在相同的外加顆粒/環氧樹 酯重量比下, 河砂組對握裹強度的改善最爲顯著, 而 標準砂的改善最小。其他如單位埋深長度的剪勁度以 及單位埋深長度的臨界剪載重等的握裹特性都與握裹 強度有類似的趨勢。由這些試驗的結果可以發現外加 顆粒本身的不規則形狀所導致的楔形效應對握裹的改 善貢獻很大。由電化學試驗來查驗塗層材料的抗蝕特 性, 結果顯示出在環氧樹酯内加入顆粒並不會影響到 塗層本身的抗蝕能力。

關鍵字: 握裹強度; 環氧樹酯塗層; 防蝕能力。 